\title{
Emerytura policyjna - jedno świadczenie o wielu elementach warunkujących jego kształt
}

\section{Wprowadzenie}

Przedmiotem rozważań niniejszego artykułu są uprawnienia przysługujące policjantom w zakresie świadczeń emerytalnych, które w ostatnim czasie spowodowały wiele kontrowersji zarówno wśród obecnych i byłych funkcjonariuszy, jak i wśród kandydatów do tej formacji oraz opinii publicznej ${ }^{1}$. Ze względu na występowanie preferencyjnych świadczeń emerytalnych wśród tej grupy mundurowej uzasadnione jest omówienie podstawowych celów funkcjonowania Policji.

Polska zgodnie z postanowieniami Konstytucji Rzeczypospolitej Polskiej $^{2}$ jest demokratycznym państwem prawnym (art. 2), które "strzeże niepodległości i nienaruszalności swojego terytorium, zapewnia wolności i prawa człowieka i obywatela oraz bezpieczeństwo obywateli [...]" (art. 5). Sa to główne zadania i zobowiązania państwa w stosunku do swoich obywateli, które państwo realizuje za pośrednictwem podległych mu instytucji. Spośród instytucji zapewniających bezpieczeństwo obywatelom jedną z głównych ról pełni Policja, którą utworzono jako

${ }^{1}$ Por. Protest mundurowych trwa. Resort odnosi się do postulatów zwiazkowców, https:// www.tvn24.pl/wiadomosci-z-kraju,3/mswia-i-zwiazki-zawodowe-sluzb-mundurowychszukaja-porozumienia,857761.html (dostęp: 28 VIII 2018); Ubywa chętnych do pracy w policji. "Istnieje problem jakości kandydatów”, https://www.tvn24.pl/wiadomosci-z-kraju,3/ mniej-chetnych-do-policji-brakuje-kandydatow-odchodza-mlodzi-policjanci, 800805 . html (dostęp: 28 VIII 2018); Praca w policji: wakatów coraz więcej, chętnych coraz mniej, https://gloswielkopolski.pl/praca-w-policji-wakatow-coraz-wiecej-chetnych-corazmniej/ar/12467360 (dostęp: 28 VIII 2018).

${ }^{2}$ Konstytucja Rzeczypospolitej Polskiej z dnia 2 IV 1997 r. (Dz.U. Nr 78, poz. 483 ze zm.), dalej „Konstytucja RP”. 
„umundurowaną i uzbrojoną formację służącą społeczeństwu i przeznaczoną do ochrony bezpieczeństwa ludzi oraz do utrzymywania bezpieczeństwa i porządku publicznego [... $]^{\prime \prime}$.

Ze względu na udzielenie Policji daleko idących uprawnień w stosunku do obywateli i osób przebywających na terenie Polski (m.in. możliwość zatrzymywania osób, dokonywania ich przeszukania, legitymowania, a nawet inwigilowania ${ }^{4}$ ) oraz nałożony obowiązek ochrony bezpieczeństwa i porządku publicznego wprowadzone zostały ograniczenia związane z możliwością wstąpienia kandydatów w szeregi tej formacji. Pomimo wynikającego z art. 65 Konstytucji RP oraz art. 10 Ustawy z dnia 26 czerwca 1974 r. Kodeks pracy ${ }^{5}$ prawa do pracy uprawnienie to nie ma charakteru absolutnego i podlega pewnym ograniczeniom. W stosunku do kandydatów, którzy chcą wstąpić w szeregi Policji, ustawodawca w art. 25 ust. 1 UoP określił, że służbę „może pełnić obywatel polski o nieposzlakowanej opinii, który nie był skazany prawomocnym wyrokiem sądu za przestępstwo lub przestępstwo skarbowe, korzystający z pełni praw publicznych, posiadający co najmniej wykształcenie średnie lub średnie branżowe oraz zdolność fizyczną i psychiczną do służby w formacjach uzbrojonych, podległych szczególnej dyscyplinie służbowej, której gotów jest się podporządkować, a także dający rękojmię zachowania tajemnicy stosownie do wymogów określonych w przepisach o ochronie informacji niejawnych"6.

Powyższe uprawnienia, warunki stawiane przed funkcjonariuszami oraz daleko idące zobowiązania - m.in. pełnienia służby nawet

${ }^{3}$ Artykuł 1 ust. 1 Ustawy z dnia 6 IV 1990 r. o Policji (tekst jedn. Dz.U 2017, poz. 2067 ze zm.), dalej „UoP”.

${ }^{4}$ Uprawnienia policjantów uregulowane są w ustawie o Policji, aktach wykonawczych wydanych na jej podstawie, m.in. w Rozporządzeniu Rady Ministrów z dnia 29 IX 2015 r. w sprawie postępowania przy wykonywaniu niektórych uprawnień policjantów (Dz.U. 2015, poz. 1565), Wytycznych nr 3 Komendanta Głównego Policji z dnia 30 VIII 2017 r. w sprawie wykonywania niektórych czynności dochodzeniowo-śledczych przez policjantów (Dz.Urz. KGP 2017, poz. 59), Zarządzeniu nr 30 Komendanta Głównego Policji z dnia 22 IX 2017 r. w sprawie pełnienia służby na drogach (Dz.Urz. KGP 2017, poz. 64), Zarządzeniu nr 360 Komendanta Głównego Policji z dnia 26 III 2009 r. w sprawie metod i form wykonywania przez policjantów konwojów i doprowadzeń (Dz.Urz KGP. 2009 Nr 6, poz. 29) oraz innych aktach prawnych, takich jak Ustawa z dnia 6 VI 1997 r. Kodeks postępowania karnego (tekst jedn. Dz.U. 2017, poz. 1904 ze zm.), Ustawa z dnia 24 VIII 2001 r. Kodeks postępowania w sprawach o wykroczenia (tekst jedn. Dz.U. 2018, poz. 475 ze zm.) czy Ustawa z dnia 28 XI 2014 r. o ochronie i pomocy dla pokrzywdzonego i świadka (Dz.U. 2015, poz. 21).

${ }^{5}$ Tekst jedn. Dz.U. 2018, poz. 917 ze zm.

${ }^{6}$ Artykuł 25 ust. 1 UoP. 
z narażeniem życia ${ }^{7}$ - powodują, że stosunek zatrudnienia policjantów jest stosunkiem specyficznym, opartym na przepisach prawa administracyjnego. Stosunek zatrudnienia policjantów pomimo wielu podobieństw do zatrudnienia opartego na prawie pracy nie jest $\mathrm{z}$ nim tożsamy ${ }^{8}$. Trafnie wskazał Sąd Najwyższy (SN) w wyroku z dnia 5 marca 1997 r., że "chociaż stosunek ten [stosunek służbowy Policjanta - dop. Ł.K.] nawiązuje się w wyniku mianowania, znanego kodeksowi pracy, na podstawie dobrowolnego zgłoszenia się do służby, stosunek ten ma zasadniczo inny charakter. Wynika to zwłaszcza z obowiązku wykonywania przez policjanta rozkazów i poleceń jego przełożonych, możliwości powierzania mu pełnienia obowiązków służbowych na innym stanowisku oraz wyznaczania i przenoszenia go na różne stanowiska, nawet w innej miejscowości, stosownie do potrzeb Policji. $Z$ drugiej strony korzysta on z pewnych preferencji w sferze materialnej, socjalnej czy ubezpieczenia społecznego ${ }^{\prime \prime}$. Wśród wskazanych preferencji znajdują się świadczenia emerytalne, które obecnie realizowane są w trzech wariantach. Warianty te można roboczo nazwać: "stara emerytura (na starych i nowych zasadach)" oraz "nowa emerytura”. Dodatkowym elementem mającym wpływ na wysokość emerytur jest wprowadzenie zmian w ustawie regulującej przyznawanie emerytur funkcjonariuszom, która potocznie określana jest jako ustawa dezubekizacyjna ${ }^{10}$.

Celem niniejszego artykułu jest wskazanie przepisów prawnych oraz determinant warunkujących przyznanie oraz wysokość świadczenia emerytalnego przysługującego funkcjonariuszom Policji.

\section{Ogólnie o emeryturze policjanta}

W chwili wejścia w życie Konstytucji RP w słowniku pojęć języka prawnego znalazło się pojęcie "zabezpieczenie społeczne”, w którego granicach

\footnotetext{
${ }^{7}$ Artykuł 27 ust. 1 UoP.

${ }^{8}$ T. Liszcz, Prawo pracy, Warszawa 2008, s. 19.

${ }^{9}$ Wyrok Naczelnego Sądu Administracyjnego (NSA) z 5 III 1997 r., sygn. II SA 1260/96, LEX nr 31621.

${ }^{10}$ Ustawa z dnia 16 XII 2016 r. o zmianie ustawy o zaopatrzeniu emerytalnym funkcjonariuszy Policji, Agencji Bezpieczeństwa Wewnętrznego, Agencji Wywiadu, Służby Kontrwywiadu Wojskowego, Służby Wywiadu Wojskowego, Centralnego Biura Antykorupcyjnego, Straży Granicznej, Biura Ochrony Rządu, Państwowej Straży Pożarnej i Służby Więziennej oraz ich rodzin (Dz.U. poz. 2270).
} 
mieszczą się uprawnienia emerytalno-rentowe ${ }^{11}$. Powyższe reguluje art. 67 Konstytucji RP, który wprost wskazuje, że "obywatel ma prawo do zabezpieczenia społecznego $\mathrm{w}$ razie niezdolności do pracy ze względu na chorobę lub inwalidztwo oraz po osiągnięciu wieku emerytalnego". Wśród uzasadnień prawnych Trybunału Konstytucyjnego (TK) można zauważyć pogląd, że zabezpieczenie to polega w głównej mierze na przysługujących obywatelom świadczeniach, których celem jest zaspokojenie usprawiedliwionych potrzeb w przypadku utraty zdolności do pracy, ograniczenia tej zdolności albo obciążenia kosztami utrzymania rodziny ${ }^{12}$.

Artykuł 67 Konstytucji RP nie wskazuje, jakie elementy składają się na zabezpieczenie społeczne, jednak przyjmuje się, że w jego skład wchodzi ubezpieczenie społeczne, zaopatrzenie społeczne i pomoc społeczna ${ }^{13}$. Jednym z elementów systemu zabezpieczenia społecznego jest zabezpieczenie emerytalne, które ze względu na swoje właściwości podmiotowe i przedmiotowe nazywane jest systemem emerytalnym ${ }^{14}$. Biorąc pod uwagę łączne uregulowanie świadczeń emerytalnych z rentowymi, system ten nazywany jest całościowo systemem emerytalno-rentowym. Jak wskazuje TK, co do zasady system emerytalny powinien mieć powszechny i jednolity charakter ${ }^{15}$, jednakże pod warunkiem poszanowania istoty prawa do zabezpieczenia społecznego ustawodawca może swobodnie modyfikować wysokość świadczeń oraz przesłanki ich przyznawania ${ }^{16}$.

Obecnie można mówić o kilku systemach emerytalno-rentowych, jednak jako podstawowy system ustawodawca wskazał powszechny system emerytalno-rentowy. Ze względu na szczególne cechy niektórych grup zawodowych również da się wyróżnić osobne systemy emerytalno-rentowe dla żołnierzy zawodowych, funkcjonariuszy służb mundurowych (Policji, Agencji Bezpieczeństwa Wewnętrznego, Agencji Wywiadu, Służby Kontrwywiadu Wojskowego, Służby Wywiadu Wojskowego, Centralnego Biura Antykorupcyjnego, Straży Granicznej, Służby Ochrony Państwa, Państwowej Straży Pożarnej, Służby Celno-Skarbowej, Służby Więziennej), sędziów, prokuratorów oraz rolników.

${ }_{11}$ M. Zieleniecki, Prawo do zabezpieczenia społecznego, "Gdańskie Studia Prawnicze” 2005, t. 13, s. 579.

${ }^{12}$ Por. wyroki TK: z 20 XI 2001 r., sygn. SK 15/01, LEX nr 50251; z 7 IX 2004 r., sygn. SK 30/03, LEX nr 122366; z 31 VII 2014 r., sygn. SK 28/13, LEX nr 1491299.

${ }^{13}$ K. Kolasiński, Prawo pracy i zabezpieczenia społecznego, Toruń 2001, s. 112 i n.

${ }^{14}$ F. Chybalski, Otwarte Fundusze emerytalne w Polsce. Analiza działalności inwestycyjnej, finansów oraz decyzji członków, Warszawa 2009, s. 11.

${ }^{15}$ Wyrok TK z 21 VI 2001 r. sygn. SK 6/01, LEX nr 48446.

${ }^{16}$ Wyrok TK z 27 I 2010 r., sygn. SK 41/07, LEX nr 550921. 
Świadczenia wypłacane w ramach powszechnego systemu emerytalno-rentowego wypłacane są ze środków Funduszu Ubezpieczeń Społecznych, natomiast w przypadku formacji mundurowych świadczenia te przysługują z budżetu państwa ${ }^{17}$.

W tym miejscu należy wskazać, że świadczenia emerytalno-rentowe dla służb mundurowych mają charakter zaopatrzeniowy, a nie ubezpieczeniowy. W związku z tym są one bardziej korzystne od powszechnego systemu ubezpieczeń. Traktowanie zaopatrzenia emerytalnego policjantów w sposób uprzywilejowany jest traktowane jako rekompensata za wysokie wymagania stawiane funkcjonariuszom, w szczególności wymagania psychofizyczne, intelektualne, dyspozycyjność oraz gotowość do narażania życia i zdrowia ${ }^{18}$. W zakresie zaopatrzenia emerytalno-rentowego podobne uregulowania znajdują się w większości służb mundurowych ${ }^{19}$, np. w Wojsku Polskim ${ }^{20}$, Agencji Bezpieczeństwa Wewnętrznego, Agencji Wywiadu, Służbie Kontrwywiadu Wojskowego, Służbie Wywiadu Wojskowego, Centralnym Biurze Antykorupcyjnym, Straży Granicznej, Służbie Ochrony Państwa, Państwowej Straży Pożarnej, Służbie Celno-Skarbowej i Służbie Więziennej ${ }^{21}$.

Policjantom $\mathrm{w}$ ramach zaopatrzenia emerytalno-rentowego (podobnie jak funkcjonariuszom innych służb) przysługują świadczenia pieniężne w postaci: emerytury policyjnej, policyjnej renty inwalidzkiej, policyjnej renty rodzinnej, dodatków do emerytury lub renty, zasiłku pogrzebowego, świadczenia niepieniężnego o charakterze świadczeń socjalnych oraz prawa do lokalu mieszkalnego albo pomocy $\mathrm{w}$ budownictwie mieszkaniowym ${ }^{22}$. Przyznanie oraz zmiana świadczeń $z$ tytułu

17 Z. Knypl, Opłaty stosunkowe w egzekucji świadczeń pieniężnych, "Currenda” 2010, LEX/el.

${ }^{18}$ R. Bogdzio, Emerytury i renty stużb mundurowych, w: Stosunek mundurowy w stużbach mundurowych, pod red. W. Maciejki, P. Szustakiewicza, Warszawa 2015, s. 287 i n.

${ }_{19}$ T. Kuczyński, Uprawnienia funkcjonariusza i pracownika, w: Stosunek stużbowy, pod red. T. Kuczyńskiego, E. Mazurczak-Jasińskiej, J. Steliny, Warszawa 2011, s. 411.

${ }^{20}$ Ustawa z dnia 10 XII 1993 r. o zaopatrzeniu emerytalnym żołnierzy zawodowych oraz ich rodzin (tekst jedn. Dz.U. 2017, poz. 2225 ze zm.).

${ }^{21}$ Ustawa z dnia 18 II 1994 r. o zaopatrzeniu emerytalnym funkcjonariuszy Policji, Agencji Bezpieczeństwa Wewnętrznego, Agencji Wywiadu, Służby Kontrwywiadu Wojskowego, Służby Wywiadu Wojskowego, Centralnego Biura Antykorupcyjnego, Straży Granicznej, Służby Ochrony Państwa, Państwowej Straży Pożarnej, Służby Celno-Skarbowej i Służby Więziennej oraz ich rodzin (tekst jedn. Dz.U. 2016, poz. 132 ze zm.).

${ }^{22}$ Artykuł 2 Ustawy z dnia 18 II 1994 r. o zaopatrzeniu emerytalnym funkcjonariuszy Policji, Agencji Bezpieczeństwa Wewnętrznego, Agencji Wywiadu, Służby Kontrwywiadu Wojskowego, Służby Wywiadu Wojskowego, Centralnego Biura Antykorupcyjnego, 
zaopatrzenia emerytalnego dla funkcjonariuszy Policji odbywa się w drodze decyzji wydanej przez Dyrektora Zakładu Emerytalno-Rentowego Ministerstwa Spraw Wewnętrznych i Administracji ${ }^{23}$. Decyzje te, podobnie jak decyzje wydawane w powszechnym systemie emerytalnym, są zaskarżalne na podstawie przepisów Kodeksu postępowania cywilnego ${ }^{24}$.

\section{Emerytury policyjne}

W obecnym stanie prawnym warunki przyznania emerytury policyjnej funkcjonariuszom Policji oraz sposób jej naliczania uzależnione są od chwili wstąpienia funkcjonariusza do służb. Ustawodawca wyróżnia dwie daty graniczne, które wyznaczają trzy sposoby udzielania świadczeń emerytalnych. Jak już wcześniej wspomniano, są to uprawnienia do "starej emerytury (na starych i nowych zasadach)” oraz "nowej emerytury".

\section{1. „Stara” emerytura}

Funkcjonariuszom Policji, którzy zostali przyjęci do służby przed 31 grudnia 2012 r., przysługuje emerytura policyjna, jeśli w dniu zwolnienia ze służby mają wysługę 15 lat służby w Policji ${ }^{25}$. Powyższe uprawnienie emerytalne nazywane jest "starą emeryturą". Świadczenie emerytalne, które może zostać przyznane po 15 latach służby, nie dotyczy tych funkcjonariuszy, którzy mają ustalone prawo do emerytur określonych w ustawie o emeryturach i rentach z Funduszu

Straży Granicznej, Służby Ochrony Państwa, Państwowej Straży Pożarnej, Służby Celno-Skarbowej i Służby Więziennej oraz ich rodzin (tekst jedn. Dz.U. 2016, poz. 132 ze zm.), dalej „ustawa o zaopatrzeniu emerytalnym funkcjonariuszy służb mundurowych”.

${ }^{23}$ Paragraf 2 ust. 1 Rozporządzenia Ministra Spraw Wewnętrznych i Administracji z dnia 2 III 2004 r. w sprawie organu emerytalnego właściwego do ustalenia prawa do zaopatrzenia emerytalnego funkcjonariuszy Policji, Urzędu Ochrony Państwa, Agencji Bezpieczeństwa Wewnętrznego, Agencji Wywiadu, Centralnego Biura Antykorupcyjnego, Straży Granicznej, Biura Ochrony Rządu i Państwowej Straży Pożarnej oraz ich rodzin (tekst jedn. Dz.U. 2016, poz. 97 ze zm.).

${ }^{24}$ Artykuł 32 ust. 4 ustawy o zaopatrzeniu emerytalnym funkcjonariuszy służb mundurowych.

${ }^{25}$ Artykuł 12 ust. 1 ustawy o zaopatrzeniu emerytalnym funkcjonariuszy służb mundurowych. 
Ubezpieczeń Społecznych obliczonej z uwzględnieniem okresów służby i okresów z nią równorzędnych. Do okresu służby, który upoważnia funkcjonariusza do przejścia w stan spoczynku zgodnie $\mathrm{z}$ art. 13 ust. 1 ustawy o zaopatrzeniu emerytalnym funkcjonariuszy służb mundurowych, zalicza się służbę w Agencji Bezpieczeństwa Wewnętrznego, Agencji Wywiadu, Służbie Kontrwywiadu Wojskowego, Służbie Wywiadu Wojskowego, Centralnym Biurze Antykorupcyjnym, Straży Granicznej, Służbie Ochrony Państwa, Państwowej Straży Pożarnej, Służbie Celnej, Służbie Celno-Skarbowej, Służbie Więziennej. W punkcie 1 powyższej jednostki redakcyjnej ustawodawca wskazał, że za równorzędne ze służbą w Policji oraz wyżej wskazanych formacjach uznaje się również:

1. okresy służby w charakterze funkcjonariusza Urzędu Ochrony Państwa lub Biura Ochrony Rządu;

2. okresy służby w charakterze funkcjonariusza Policji Państwowej lub Milicji Obywatelskiej;

3. okresy służby na rzecz totalitarnego państwa;

4. służbę wojskową uwzględnianą przy ustalaniu prawa do emerytury wojskowej;

5. okresy służby w charakterze funkcjonariusza Służby Ochrony Kolei, jeżeli funkcjonariusz przeszedł bezpośrednio do służby w Milicji Obywatelskiej lub w Służbie Więziennej w terminie do dnia 1 kwietnia 1955 r.;

6. okresy zatrudnienia lub służby w zawodowych jednostkach ochrony przeciwpożarowej i nauki w szkołach pożarniczych, w charakterze członka Korpusu Technicznego Pożarnictwa, a także funkcjonariusza pożarnictwa w terminie do dnia 31 stycznia $1992 \mathrm{r}$.

Natomiast funkcjonariusz, który zgodnie z art. 13 ust. 1 ustawy o zaopatrzeniu emerytalnym funkcjonariuszy służb mundurowych pełnił służbę "W latach 1944-1956 w charakterze funkcjonariusza organów bezpieczeństwa państwa, porządku i bezpieczeństwa publicznego, jeżeli przy wykonywaniu czynności służbowych funkcjonariusz popełnił przestępstwo przeciwko wymiarowi sprawiedliwości lub naruszające dobra osobiste obywatela i za to został zwolniony dyscyplinarnie, umorzono wobec niego postępowanie karne ze względu na znikomy lub nieznaczny stopień społecznego niebezpieczeństwa czynu lub został skazany z winy umyślnej prawomocnym wyrokiem sądu", nie może traktować okresów tej służby jako okresów równorzędnych i nie uwzględnia się ich przy obliczaniu emerytury. 
Wysokość emerytury obliczanej dla funkcjonariusza jest uzależniona od tego, kiedy policjant pierwszy raz został wcielony do służb mundurowych. Wszyscy policjanci, którzy zostali przyjęci do służby przed 31 grudnia 2012 r. i przysługuje im "stara emerytura”, mogą liczyć na otrzymanie świadczenia emerytalnego w wysokości $40 \%$ podstawy wymiaru za 15 lat służby ${ }^{26}$. Maksymalny wymiar emerytury wynosi 75\% uposażenia ${ }^{27}$ przysługującego policjantowi na ostatnio zajmowanym stanowisku ${ }^{28}$. Wśród tych funkcjonariuszy różnice w sposobie naliczania emerytury dotyczą podwyższania emerytury, dlatego też w ramach "starej emerytury" wyróżnić trzeba "starą emeryturę na starych zasadach" i "starą emeryturę na nowych zasadach".

\subsection{1. „Stara” emerytura na starych zasadach}

Policjant, który pozostawał w służbie przed dniem 2 stycznia $1999 \mathrm{r}$. otrzyma "starą emeryturę na starych zasadach", do której będzie mógł doliczyć okresy składkowe oraz nieskładkowe przypadające przed jego przyjęciem do służby. Powyższe oznacza, że podstawowy wymiar emerytury funkcjonariusza ( $40 \%$ podstawy po 15 latach służby) może zostać podwyższony z następujących tytułów ${ }^{29}$ :

1. za każdy dalszy rok tej służby o $2,6 \%$ podstawy wymiaru;

2. za każdy rok okresów składkowych poprzedzających służbę (nie więcej jednak niż za trzy lata tych okresów) o 2,6\% podstawy wymiaru, a za każdy rok okresów składkowych ponad ten trzyletni okres o 1,3\% podstawy wymiaru;

3. za każdy rok okresów nieskładkowych poprzedzających służbę o $0,7 \%$ podstawy wymiaru.

Dodatkowo na podstawie art. 14 ust. 2 ustawy o zaopatrzeniu emerytalnym funkcjonariuszy służb mundurowych funkcjonariusz może doliczyć do wysługi emerytalnej okresy przypadające po zwolnieniu ze służby, jeżeli jego emerytura wynosi mniej niż 75\%

${ }^{26}$ Artykuł 15 ust. 1 oraz art. 15a ustawy o zaopatrzeniu emerytalnym funkcjonariuszy służb mundurowych.

${ }^{27}$ Artykuł 18 ust. 1 ustawy o zaopatrzeniu emerytalnym funkcjonariuszy służb mundurowych.

${ }^{28}$ Artykuł 5 ust. 1 ustawy o zaopatrzeniu emerytalnym funkcjonariuszy służb mundurowych.

${ }^{29}$ Artykuł 15 ust. 1 pkt 1-4 ustawy o zaopatrzeniu emerytalnym funkcjonariuszy służb mundurowych. 
podstawy świadczenia oraz ukończył on: w przypadku kobiet 50 lat życia, a w przypadku mężczyzn 55 lat życia. Uprawnienie takie przysługuje również, jeżeli policjant stał się inwalidą. Doliczeniu podlegają okresy dotyczące ${ }^{30}$ :

1. zatrudnienia przed dniem 1 stycznia 1999 r. w wymiarze czasu pracy nie niższym niż połowa pełnego wymiaru czasu pracy;

2. opłacania składek na ubezpieczenia emerytalne i rentowe po dniu 31 grudnia 1998 r. lub okres nieopłacania składek z powodu przekroczenia $w$ trakcie roku kalendarzowego kwoty rocznej podstawy wymiaru składek na te ubezpieczenia;

3. osadzenia w więzieniach lub innych miejscach odosobnienia na terytorium Polski na mocy skazania albo bez wyroku po dniu 31 grudnia 1955 r. za działalność polityczną;

4. świadczenia pracy po 1956 r. na rzecz organizacji politycznych i związków zawodowych, nielegalnych w rozumieniu przepisów obowiązujących do kwietnia 1989 r.;

5. niewykonywania pracy przed dniem 31 lipca 1990 r. na skutek represji politycznych;

6. internowania na podstawie art. 42 Dekretu z dnia 12 grudnia $1981 \mathrm{r}$. o stanie wojennym ${ }^{31}$.

Powyższe uprawnienia przysługujące policjantom, którzy pełnili służbę przed 1 stycznia 1999 r., są bardzo korzystne, ponieważ pozwalają na zwiększenie świadczenia emerytalnego o okresy poprzedzające służbę. Ze względu na to wielu policjantów starało się wykazać, że pełniło służbę przed 1 stycznia 1999 r., m.in. poprzez odbycie zasadniczej służby wojskowej. W orzecznictwie sądów administracyjnych ugruntowało się podejście, które wskazuje, że zasadniczej służby wojskowej nie należy traktować jako służby w rozumieniu ustawy o zaopatrzeniu emerytalnym funkcjonariuszy ${ }^{32}$. Co prawda, zasadnicza służba wojskowa uprawnia do zaliczenia tego okresu jako okresu równorzędnego do naliczenia świadczenia emerytalnego, jednak nie uprawnia do przyjęcia, że zasadnicza służba wojskowa pełniona przed 1 stycznia $1999 \mathrm{r}$. jest jednoznaczna z pojęciem przyjęcia do służby. Powyższe wiąże się z interpretacją terminu "przyjęcie do służby", w związku z czym sądy administracyjne wskazuja, że "przyjęcie do służby" jest dobrowolnym

${ }^{30}$ Artykuł 14 ust. 1 ustawy o zaopatrzeniu emerytalnym funkcjonariuszy służb mundurowych.

${ }^{31}$ Dz.U. Nr 29, poz. 154, Dz.U. 1982 Nr 3, poz. 18, oraz Dz.U. 1989 Nr 34, poz. 178.

${ }^{32}$ Wyrok Sądu Apelacyjnego z 4 XI 2015 r., sygn. III AUa 1475/14, LEX nr 1934404. 
aktem funkcjonariusza, natomiast zasadnicza służba wojskowa wiązała się z przymusowym poborem ${ }^{33}$.

\subsection{2. „Stara" emerytura na nowych zasadach}

W przypadku funkcjonariusza, który został przyjęty do służby po raz pierwszy po 1 stycznia 1999 r., podstawa wymiaru świadczenia po przesłużeniu 15 lat wynosi również 40\%, jednak wzrasta wyłącznie w wymiarze $2,6 \%$ podstawy za każdy dalszy rok tej służby. Policjanci przyjęci do służby po 1 stycznia 1999 r. nie mają możliwości dodatkowego doliczenia do wymiaru emerytury okresów składkowych oraz nieskładkowych. Emeryturę, która przysługuje funkcjonariuszowi przyjętemu do służby po 1 stycznia 1999 r., nazywa się „starą emeryturą na nowych zasadach".

\subsubsection{Elementy wspólne}

Ustawodawca w ustawie o zaopatrzeniu emerytalnym funkcjonariuszy przewidział pewne przypadki wspólne zarówno dla funkcjonariuszy Policji, którzy zostali wcieleni do służby przed, jak i po 2 stycznia 1999 r., których spełnienie upoważnia takich policjantów do otrzymania wyższej emerytury. Zgodnie $z$ art. 15 ust. 2-5 ustawy o zaopatrzeniu emerytalnym świadczenie emerytalne podlega wzrostowi w przypadku:

1. służby pełnionej bezpośrednio w charakterze nurków i płetwonurków oraz w zwalczaniu fizycznym terroryzmu

- o $2 \%$ podstawy wymiaru za każdy rok;

2. za każdy rok służby pełnionej bezpośrednio:

a. w składzie personelu latającego na samolotach i śmigłowcach,

b. w składzie załóg nawodnych jednostek pływających,

c. w charakterze skoczków spadochronowych i saperów,

d. w służbie wywiadowczej za granica

- o $1 \%$ podstawy wymiaru;

3. za każdy rok służby pełnionej w warunkach szczególnie zagrażających życiu i zdrowiu - o 0,5\% podstawy wymiaru;

4. za każdy rozpoczęty miesiąc pełnienia służby na froncie w czasie wojny oraz w strefie działań wojennych - o 0,5\% podstawy wymiaru.

${ }^{33}$ Wyrok SN z 11 IV 2017 r., sygn. II UK 118/16, LEX nr 2312477. 
Dodatkowo emeryturę podwyższa się o $15 \%$ podstawy wymiaru emerytowi, którego inwalidztwo pozostaje w związku ze służbą (w takim przypadku wysokość emerytury nie może przekroczyć $80 \%$ podstawy jej wymiaru $\left.{ }^{34}\right)$.

Przy dokonywaniu oceny zasadności podwyższenia świadczenia emerytalnego należy posiłkować się Rozporządzeniem Rady Ministrów z dnia 4 maja 2005 r. w sprawie szczegółowych warunków podwyższania emerytur funkcjonariuszy Policji, Agencji Bezpieczeństwa Wewnętrznego, Agencji Wywiadu, Służby Kontrwywiadu Wojskowego, Służby Wywiadu Wojskowego, Centralnego Biura Antykorupcyjnego, Straży Granicznej, Biura Ochrony Rządu, Państwowej Straży Pożarnej i Służby Więziennej ${ }^{35}$. Rozporządzenie to określa m.in. sytuacje, które umożliwiają uznanie służby w Policji za służbę pełnioną w warunkach szczególnie zagrażających życiu i zdrowiu. W tym przypadku wskazuje się, że warunki te polegają na ${ }^{36}$ :

1. podjęciu co najmniej 6 razy w ciągu roku czynności służbowych w celu ochrony osób, mienia lub przywrócenia porządku publicznego w sytuacjach, w których istniało bezpośrednie zagrożenie życia lub zdrowia;

2. uczestniczeniu co najmniej przez 30 dni w ciągu roku w fizycznej ochronie osób lub mienia w warunkach, w których istniało bezpośrednie zagrożenie życia lub zdrowia;

3. wzięciu udziału w działaniach ratowniczych, w tym ratowniczogaśniczych lub kierowaniu bezpośrednio tymi działaniami na miejscu zdarzenia - co najmniej przez 30 dni w ciągu roku;

4. braniu udziału przez co najmniej 8 miesięcy w ciągu roku w wypełnianiu zadań w zakresie bezpośredniej ochrony i opieki nad osadzonymi:

a. w oddziałach dla nosicieli wirusa HIV, dla osadzonych wymagających stosowania szczególnych środków leczniczo-wychowawczych i osadzonych szczególnie niebezpiecznych w okresie do dnia 31 sierpnia 1998 r.;

\footnotetext{
${ }^{34}$ Artykuł 18 ust. 1 ustawy o zaopatrzeniu emerytalnym funkcjonariuszy służb mundurowych.

${ }^{35}$ Dz.U. Nr 86, poz. 734 ze zm.

${ }^{36}$ Paragraf 3 Rozporządzenia Rady Ministrów z dnia 4 V 2005 r. w sprawie szczegółowych warunków podwyższania emerytur funkcjonariuszy Policji, Agencji Bezpieczeństwa Wewnętrznego, Agencji Wywiadu, Służby Kontrwywiadu Wojskowego, Służby Wywiadu Wojskowego, Centralnego Biura Antykorupcyjnego, Straży Granicznej, Biura Ochrony Rządu, Państwowej Straży Pożarnej i Służby Więziennej (Dz.U. Nr 86, poz. 734 ze zm.).
} 
b. w oddziałach dla osadzonych niebezpiecznych i w oddziałach terapeutycznych dla skazanych z zaburzeniami psychicznymi lub upośledzonych umysłowo.

W powyższym katalogu problemy natury interpretacyjnej i dowodowej przynosi stosowanie przesłanki polegającej na podjęciu przez funkcjonariusza "co najmniej 6 razy w ciągu roku czynności służbowych w celu ochrony osób, mienia lub przywrócenia porządku publicznego w sytuacjach, w których istniało bezpośrednie zagrożenie życia lub zdrowia". Trybunał Konstytucyjny wskazał, że określona rozporządzeniem Rady Ministrów przesłanka polegająca na podjęciu sześciu interwencji, "W których istniało bezpośrednie zagrożenie życia lub zdrowia", jest niezgodna z Konstytucją RP, a dokładnie z jej art. 92 ust. $1^{37}$. Powyższe wynika $\mathrm{z}$ faktu, że w art. 15 ust. 2 pkt 3 ustawy o zaopatrzeniu emerytalnym funkcjonariuszy służb mundurowych ustawodawca wskazał, iż pełnienie służby umożliwiające staranie się o podwyższenie emerytury musiało nastąpić "w warunkach szczególnie zagrażających życiu i zdrowiu", a nie w warunkach bezpośrednio zagrażających życiu lub zdrowiu. Jak wynika $z$ roty ślubowania policjantów ${ }^{38}$, ich służba jest pełniona z narażeniem życia i zdrowia. Dodatkowo służba każdego dnia wiąże się z wieloma zagrożeniami. Ze względu na to trudno określić, co oznaczają szczególne warunki zagrażające życiu i zdrowiu. Sądy administracyjne wskazały, że codzienne obowiązki i czynności służbowe, które wynikają z zajmowanego stanowiska służbowego lub pełnionej funkcji, nie mogą być uznane za szczególnie zagrażające życiu i zdrowiu nawet w przypadku działań ochronnych lub zabezpieczających, które są realizowane z bronią palną. Tak samo nie można zakwalifikować do tej kategorii zdarzeń wypadków w służbie, które nie miały związku z podejmowanymi czynnościami służbowymi ${ }^{39}$. Zdarzeniami kwalifikującymi się do sytuacji "szczególnie zagrażających życiu i zdrowiu” są zagrożenia rozumiane jako zagrożenia inne niż normalne następstwa pełnienia służby, które mają charakter wyjątkowy ${ }^{40}$. Często wskazuje się, że są to zagrożenia porównywalne do naruszenia nietykalności cielesnej, choć należy wskazać, że nigdzie nie został sporządzony enumeratywny lub przykładowy wykaz takich zagrożeń.

\footnotetext{
${ }^{37}$ Wyrok TK z 27 V 2014 r., sygn. U 12/13, LEX nr 1466317.

${ }^{38}$ Artykuł 27 ust. 1 UoP.

${ }^{39}$ Wyrok Wojewódzkiego Sądu Administracyjnego (WSA) w Warszawie z 6 X 2017 r., sygn. II SA/Wa 211/17, LEX nr 2404426.

${ }^{40}$ Wyrok WSA w Warszawie z 15 XII 2017 r., sygn. II SA/Wa 562/17, LEX nr 2449615.
} 
Wskazane Rozporządzenie Rady Ministrów precyzuje, jakie zachowania ogólnie umożliwiają podniesienie emerytury. Co do przesłanek określonych miejscem pełnienia służby lub wykonywaniem określonych czynności nie ma większego problemu z ich potwierdzeniem. Problem dla funkcjonariusza pojawia się w przypadku wnioskowania o poświadczenie udziału w zdarzeniach szczególnie zagrażających życiu i zdrowiu, ponieważ organ nie ma obowiązku prowadzenia rejestrów, w których są one odnotowywane. Fakt, że każda podjęta interwencja pozostawia po sobie ślad w zapisach, m.in. w notatnikach służbowych, nie daje podstaw do twierdzenia, że będzie można potwierdzić takie zdarzenie, chociażby po zakończeniu okresu archiwizacyjnego i zniszczeniu dokumentacji obrazującej taką interwencję ${ }^{41}$. Słusznie wskazano w jednym z wyroków Sądu Administracyjnego, że "przepis art. 15 ust. 2 pkt 3 ustawy gwarantuje funkcjonariuszom prowadzenie przez organy Policji takich dokumentów policyjnych, które pozwoliłyby na gromadzenie danych o faktach wskazujących na pełnienie służby w warunkach szczególnie zagrażających życiu i zdrowiu, co umożliwia potwierdzenie lub odmowę potwierdzenia owych warunków w zaświadczeniu"42. Na wniosek zainteresowanego funkcjonariusza organ wydaje zaświadczenie, które wskazuje, czy policjant brał udział w zdarzeniach „podwyższonego ryzyka". Należy przy tym wskazać, że zaświadczenie jest aktem wiedzy, nie zaś woli organu i nie ma charakteru prawotwórczego, tzn. nie tworzy nowej sytuacji prawnej. Podczas prowadzenia postępowania wyjaśniającego organ powinien opierać się na dostępnych ewidencjach, rejestrach oraz innych danych, które są w jego posiadaniu. Niedopuszczalne jest dokonywanie nowych ustaleń faktycznych. Podobnie udział zainteresowanego $\mathrm{w}$ takim postępowaniu jest ograniczony, ponieważ nie przewiduje m.in. przeprowadzenia dowodów z zeznań świadków. Takie zabiegi są dozwolone w postępowaniu przed sądem powszechnym ${ }^{43}$.

\section{2. "Nowa" emerytura}

W przypadku funkcjonariuszy Policji, którzy zostali przyjęci do służby po raz pierwszy po dniu 31 grudnia 2012 r., mamy do czynienia

${ }^{41}$ Por. Policjant otrzyma wyższa emeryture, gdy potwierdza to akta, http://serwisy.gazetaprawna.pl/emerytury-i-renty/artykuly/690430 (dostęp: 28 VIII 2018).

${ }^{42}$ Wyrok WSA w Opolu z 19 XII 2013 r., sygn. II SA/Op 445/13, LEX nr 1417625.

${ }^{43}$ Wyrok NSA z 24 I 2017 r., sygn. I OSK 2554/16, LEX nr 2296522. 
z zupełnie innymi zasadami nabywania uprawnień emerytalnych. Jest to tzw. "nowa emerytura”. Ustawa z dnia 11 maja 2012 r. o zmianie ustawy o zaopatrzeniu emerytalnym żołnierzy zawodowych oraz ich rodzin, ustawy o zaopatrzeniu emerytalnym funkcjonariuszy Policji, Agencji Bezpieczeństwa Wewnętrznego, Agencji Wywiadu, Służby Kontrwywiadu Wojskowego, Służby Wywiadu Wojskowego, Centralnego Biura Antykorupcyjnego, Straży Granicznej, Biura Ochrony Rządu, Państwowej Straży Pożarnej i Służby Więziennej oraz ich rodzin oraz niektórych innych ustaw ${ }^{44}$ wprowadziła zasady, które określaja, że uzyskanie uprawnień emerytalnych wiąże się z obowiązkiem osiągnięcia określonego wieku połączonego z określoną wysługą lat służby $\mathrm{w}$ formacji. Zgodnie $\mathrm{z}$ art. 18a ust. 1 ustawy o zaopatrzeniu emerytalnym funkcjonariuszy służb mundurowych funkcjonariusze przyjęci do służby od 2013 r. nabędą prawa emerytalne po przesłużeniu w Policji co najmniej 25 lat oraz osiągnięciu wieku 55 lat ${ }^{45}$. Wysokość podstawy emerytalnej w powyższej konfiguracji wynosi $60 \%$ i wzrasta o $3 \%$ za każdy dalszy rok tej służby ${ }^{46}$. Podobnie jak w przypadku funkcjonariuszy przyjętych przed 2013 r., policjanci objęci "nową emeryturą” mogą otrzymać świadczenie emerytalne w maksymalnym wymiarze, który wynosi $75 \%$ podstawy jej wymiaru ${ }^{47}$. Oprócz kryterium wieku oraz stażu służby ustawodawca wprowadził nowe instrumenty dotyczące regulacji emerytury, które do tej pory były obce staremu systemowi zaopatrzenia emerytalnego funkcjonariuszy. Główną różnicą jest wyliczanie podstawy wymiaru emerytury funkcjonariusza, która jest wyliczana ze średniego uposażenia, które funkcjonariusz otrzymywał przez okres kolejnych 10 lat kalendarzowych, wybranych przez niego ${ }^{48}$. W przypadku braku wskazania okresu, obliczenia dokonuje się automatycznie, na podstawie

${ }^{44}$ Dz.U. poz. 664.

${ }^{45}$ Jednakże - jeżeli funkcjonariusz przyjęty do służby po dniu 31 grudnia 2012 r. pełnił wcześniej służbę w Policji, Urzędzie Ochrony Państwa, Agencji Bezpieczeństwa Wewnętrznego, Agencji Wywiadu, Służbie Kontrwywiadu Wojskowego, Służbie Wywiadu Wojskowego, Służbie Celnej, Centralnym Biurze Antykorupcyjnym, Straży Granicznej, Biurze Ochrony Rządu, Państwowej Straży Pożarnej lub Służbie Więziennej, zawodową służbę wojskową lub służbę kandydacką - ma prawo do "starej emerytury”.

${ }^{46}$ Artykuł 18e ust. 1 ustawy o zaopatrzeniu emerytalnym funkcjonariuszy służb mundurowych.

${ }^{47}$ Artykuł $18 \mathrm{~g}$ ust. 1 ustawy o zaopatrzeniu emerytalnym funkcjonariuszy służb mundurowych.

${ }^{48}$ Artykuł 18f ust. 1 ustawy o zaopatrzeniu emerytalnym funkcjonariuszy służb mundurowych. 
ostatnich 10 lat służby ${ }^{49}$. Do okresu służby, który musi wynosić minimum 25 lat, wlicza się okres urlopu wychowawczego udzielonego funkcjonariuszowi w wymiarze łącznym nie większym niż 3 lata ${ }^{50}$. Nowy system emerytalny" umożliwia podwyższenie podstawy wymiaru, jeśli policjant pełnił służbę na froncie oraz w czasie wojny i w stresie działań wojennych. W takim przypadku podwyższenie emerytury następuje o $0,5 \%$ za każdy miesiąc takiej służby ${ }^{51}$. Funkcjonariuszom pełniącym służbę od 2013 r. nie przysługują dodatkowe możliwości podnoszenia podstawy wymiaru emerytury.

W przypadku kiedy funkcjonariusz został zwolniony ze służby po osiągnięciu 25 lat służby, ale przed ukończeniem 55 lat życia, ma on możliwość otrzymania emerytury policyjnej po osiągnięciu tego wieku. Powyższe uprawnienie dotyczy funkcjonariuszy, którzy zostali zwolnieni ze służby ze względu na orzeczenie przez komisję lekarską trwałej niezdolności do służby, likwidacji jednostki Policji lub jej reorganizacji połączonej ze zmniejszeniem obsady etatowej, jeżeli przeniesienie policjanta do innej jednostki lub na niższe stanowisko służbowe nie jest możliwe ${ }^{52}$.

Zabieg ustawodawcy polegający na zmianie uprawnień emerytalnych ze starego systemu na nowy w postaci konieczności osiągnięcia wysługi 25 lat oraz osiągnięciu wieku 55 lat spowodował zahamowanie zainteresowania podjęciem służby w Policji ${ }^{53}$. W uzasadnieniu Ustawy z dnia 11 maja 2012 r. o zmianie ustawy o zaopatrzeniu emerytalnym żołnierzy zawodowych oraz ich rodzin, ustawy o zaopatrzeniu emerytalnym funkcjonariuszy Policji, Agencji Bezpieczeństwa Wewnętrznego,

${ }^{49}$ Artykuł 18f ust. 2 ustawy o zaopatrzeniu emerytalnym funkcjonariuszy służb mundurowych.

${ }^{50}$ Artykuł 18c ustawy o zaopatrzeniu emerytalnym funkcjonariuszy służb mundurowych.

${ }^{51}$ Artykuł 18e ust. 2 ustawy o zaopatrzeniu emerytalnym funkcjonariuszy służb mundurowych.

${ }^{52}$ Artykuł 18d ust. 1 pkt 1 ustawy o zaopatrzeniu emerytalnym funkcjonariuszy służb mundurowych.

${ }^{53}$ Por. Żeby zapetnić wakaty w opolskiej policji, potrzeba 2 tysiace chętnych, http://opole.wyborcza.pl/opole/7,35086,23628761,zeby-zapelnic-wakaty-w-opolskiej-policjipotrzeba-2-tysiace.html (dostęp 29 VIII 2018); Nie ma chętnych do pracy w policji, https:// innpoland.pl/143443, chcesz-pracowac-w-policji-teraz-to-latwe-maja-potezne-brakikadrowe (dostęp: 29 VIII 2018); Wakaty w policji 2018. W catym kraju brakuje 5 tysięcy 260 policjantów, https://dziennikzachodni.pl/wakaty-w-policji-2018-w-calym-kraju-brakuje5-tysiecy-260-policjantow/ar/13148580 (dostęp: 29 VIII 2018). 
Agencji Wywiadu, Służby Kontrwywiadu Wojskowego, Służby Wywiadu Wojskowego, Centralnego Biura Antykorupcyjnego, Straży Granicznej, Biura Ochrony Rządu, Państwowej Straży Pożarnej i Służby Więziennej oraz ich rodzin oraz niektórych innych ustaw, która wprowadzała powyższą zmianę, wskazywano, że głównym celem zmian jest zachęcenie policjantów do dłuższej służby, racjonalizacja wydatków budżetu państwa na zaopatrzenie emerytalne oraz opracowanie sprawnego systemu emerytalnego służb mundurowych ${ }^{54}$. Dodatkowo wskazano, że „brak jest [...] poparcia społecznego, zwłaszcza w sytuacji wprowadzenia zmian w systemie powszechnym, dla dalszego utrzymywania dotychczasowych przywilejów dla służb mundurowych, w obowiązującym dzisiaj zakresie" ${ }^{\prime 55}$. Powyższe stwierdzenie w uzasadnieniu ustawy jest sprzeczne z założeniami odrębności stosunku służbowego funkcjonariuszy służb mundurowych od prawa pracy. Z szeroko rozwijanego uzasadnienia wprowadzanych zmian sprawiedliwością społeczną największe jednak znaczenie ma czynnik ekonomiczny, ponieważ reforma będzie generowała oszczędności dla budżetu, które w 2028 r. osiągną ok. $52 \mathrm{mln}$ zł i będą wzrastać do ok. 1,4 mld zł rocznie (w ujęciu służb: Policji, Państwowej Straży Pożarnej, Służby Więziennej, Straży Granicznej, Biura Ochrony Rządu, Agencji Bezpieczeństwa Wewnętrznego, Agencji Wywiadu, Centralnego Biura Antykorupcyjnego, Służby Kontrwywiadu Wojskowego oraz Służby Wywiadu Wojskowego).

\section{Wpływ służby na rzecz totalitarnego państwa na uprawnienia emerytalne}

Wyżej wskazane uprawnienia emerytalno-rentowe podlegają ograniczeniom związanym ze służbą policjanta na rzecz totalitarnego państwa. Nowelizacja ustawy o zaopatrzeniu emerytalnym z dnia 16 grudnia 2016 r. ${ }^{56}$ wprowadziła zmiany, które w drastyczny sposób ograniczają

${ }^{54}$ Rządowy projekt ustawy o zmianie ustawy o zaopatrzeniu emerytalnym żołnierzy zawodowych oraz ich rodzin, ustawy o zaopatrzeniu emerytalnym funkcjonariuszy Policji, Agencji Bezpieczeństwa Wewnętrznego, Agencji Wywiadu, Służby Kontrwywiadu Wojskowego, Służby Wywiadu Wojskowego, Centralnego Biura Antykorupcyjnego, Straży Granicznej, Biura Ochrony Rządu, Państwowej Straży Pożarnej i Służby Więziennej oraz ich rodzin oraz niektórych innych ustaw, Druk nr 330, s. 1.

${ }^{55}$ Ibidem, s. 2.

${ }^{56}$ Ustawa z dnia 16 XII 2016 r. o zmianie ustawy o zaopatrzeniu emerytalnym funkcjonariuszy Policji, Agencji Bezpieczeństwa Wewnętrznego, Agencji Wywiadu, Służby 
świadczenia emerytalno-rentowe prawie 50 tys. byłych funkcjonariuszy oraz ich rodzinom, które pobierają świadczenia po zmarłych policjantach.

W uzasadnieniu ustawy wskazano, że jej celem jest "wprowadzenie rozwiązań zapewniających $w$ pełniejszym zakresie zniesienie przywilejów emerytalnych związanych z pracą $\mathrm{w}$ aparacie bezpieczeństwa PRL przez ustalenie na nowo świadczeń emerytalnych i rentowych osobom pełniącym służbę na rzecz totalitarnego państwa w okresie

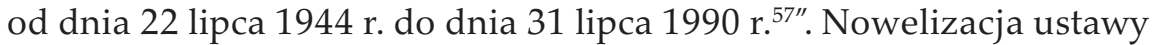
ma objąć swoimi zmianami również policyjnych rencistów, ponieważ wcześniejsza próba ograniczenia przywilejów byłych funkcjonariuszy aparatu bezpieczeństwa nie obejmowała tego zakresu ${ }^{58}$.

Jako służbę na rzecz państwa totalitarnego ustawodawca wskazał służbę w okresie od 22 lipca 1944 r. do 31 lipca 1990 r. w cywilnych i wojskowych instytucjach oraz formacjach, które określono enumeratywnie w art. 13b ustawy o zaopatrzeniu emerytalnym funkcjonariuszy służb mundurowych (m.in. szeroko pojęta służba bezpieczeństwa - na wszystkich szczeblach).

W celu ustalenia, czy funkcjonariusz pełnił służbę na rzecz totalitarnego państwa, organ emerytalny zwraca się do Instytutu Pamięci Narodowej - Komisji Ścigania Zbrodni przeciwko Narodowi Polskiemu z wnioskiem o sporządzenie informacji przebiegu służby wskazanych funkcjonariuszy na rzecz totalitarnego państwa ${ }^{59}$. Powyższa informacja jest sporządzana na podstawie posiadanych przez Instytut Pamięci Narodowej akt osobowych w terminie 4 miesięcy od otrzymania odpowiedniego wniosku.

Kontrwywiadu Wojskowego, Służby Wywiadu Wojskowego, Centralnego Biura Antykorupcyjnego, Straży Granicznej, Biura Ochrony Rządu, Państwowej Straży Pożarnej i Służby Więziennej oraz ich rodzin (Dz.U. poz. 2270).

${ }^{57}$ Rządowy projekt ustawy o zmianie ustawy o zaopatrzeniu emerytalnym funkcjonariuszy Policji, Agencji Bezpieczeństwa Wewnętrznego, Agencji Wywiadu, Służby Kontrwywiadu Wojskowego, Służby Wywiadu Wojskowego, Centralnego Biura Antykorupcyjnego, Straży Granicznej, Biura Ochrony Rządu, Państwowej Straży Pożarnej i Służby Więziennej oraz ich rodzin, Druk nr 1061, s. 1.

${ }^{58} \mathrm{Już}$ w 2009 r. ustawodawca dokonał zmiany w ustawie o zaopatrzeniu emerytalnym funkcjonariuszy (Dz.U Nr 24, poz. 145): w przypadku funkcjonariuszy, którzy pełnili służbę w organach bezpieczeństwa państwa w latach 1944-1990, emerytura wynosiła 0,7\% podstawy za każdy rok tej służby.

${ }_{59}$ Artykuł 13a ustawy o zaopatrzeniu emerytalnym funkcjonariuszy służb mundurowych. 
W przypadku funkcjonariuszy, którzy pełnili służbę na rzecz totalitarnego państwa, a następnie pozostali w służbach określonych w ustawie o zaopatrzeniu emerytalno-rentowym Policji, Agencji Bezpieczeństwa Wewnętrznego, Agencji Wywiadu, Służby Kontrwywiadu Wojskowego, Służby Wywiadu Wojskowego, Centralnego Biura Antykorupcyjnego, Straży Granicznej, Służby Ochrony Państwa, Państwowej Straży Pożarnej, Służby Celno-Skarbowej i Służby Więziennej, emerytura wynosi ${ }^{60}$ :

$1.0 \%$ podstawy wymiaru - za każdy rok służby na rzecz totalitarnego państwa;

2. 2,6\% podstawy wymiaru - za każdy rok służby lub okresów równorzędnych ze służbą.

Do uprawnień emerytalnych wskazanych funkcjonariuszy stosuje się przepisy polegające na zwiększaniu emerytury z tym zastrzeżeniem, że jej wysokość nie może być wyższa niż miesięczna kwota przeciętnej emerytury wypłaconej przez Zakład Ubezpieczeń Społecznych z Funduszu Ubezpieczeń Społecznych, ogłoszonej przez Prezesa Zakładu Ubezpieczeń Społecznych ${ }^{61}$.

Zmiany wprowadzone ustawą dezubekizacyjną dotknęły również rodziny funkcjonariuszy. Świadczenia po poległych policjantach przyznawane rodzinom podlegaja pomniejszeniu na takich samych zasadach jak emerytury i renty żyjących funkcjonariuszy. W przypadku rodzin funkcjonariuszy, którzy po 31 lipca 1990 r. zginęli w związku z pełnieniem służby albo ponieśli śmierć $w$ wypadkach pozostających w związku z pełnieniem służby, przysługuje im świadczenie w pełnej wysokości ${ }^{62}$.

Ustawodawca przewidział jednak odstępstwa od powyższych regulacji. Artykułem 8a ustawy o zaopatrzeniu emerytalnym funkcjonariuszy służb mundurowych wprowadzono „akt łaski” ministra właściwego do spraw wewnętrznych. Polega on na tym, że w przypadku, kiedy policjant pełnił krótkotrwałą służbę przed dniem 31 lipca 1990 r. na rzecz państwa totalitarnego, a następnie rzetelnie wykonywał zadania i obowiązki po dniu 12 września 1989 r., w szczególności z narażeniem zdrowia i życia, minister może w drodze indywidualnej decyzji wyłączyć zastosowanie

${ }^{60}$ Artykuł 15c ust. 1 ustawy o zaopatrzeniu emerytalnym funkcjonariuszy służb mundurowych.

${ }^{61}$ Artykuł 15c ust. 3 ustawy o zaopatrzeniu emerytalnym funkcjonariuszy służb mundurowych.

${ }^{62}$ Artykuł 24a ust. 5 ustawy o zaopatrzeniu emerytalnym funkcjonariuszy służb mundurowych. 
restrykcji związanych z możliwością otrzymania świadczenia emerytalnego w maksymalnej kwocie odpowiadającej przeciętnej miesięcznej emeryturze wypłacanej z Funduszu Ubezpieczeń Społecznych. Dodatkowo wskazanej restrykcji nie stosuje się, jeśli funkcjonariusz wykaże, że przed rokiem 1990 bez wiedzy przełożonych podjął współpracę i czynnie wspierał osoby lub organizacje działające na rzecz niepodległości Państwa Polskiego.

Powyższy zabieg spowodował, że osoby, które pełniły służbę na rzecz państwa totalitarnego - bez względu na to, czy podlegają wyłączeniu albo prawu łaski - a obecnie pobierają świadczenia emerytalno-rentowe, automatycznie zostały objęte zmianami ${ }^{63}$. Skutkuje to składaniem odwołań i wniosków o zastosowanie aktu łaski przez tysiące uprawnionych do pobierania świadczeńn ${ }^{64}$. Ze względu na liczbę postępowań zachowanie terminów procesowych jest niemożliwe ${ }^{65}$. Dodatkowo 24 stycznia 2018 r. sędzia Sądu Okręgowego w Warszawie sporządził pytanie prawne do Trybunału Konstytucyjnego w celu zbadania, czy obniżenie świadczenia przez Zakład Emerytalno-Rentowy MSWiA na podstawie ustawy dezubekizacyjnej jest zgodne z ustawą zasadniczą ${ }^{66}$ "z uwagi na ukształtowanie regulacji ustawowej w sposób ograniczający wysokość emerytury i renty mimo odpowiedniego okresu służby, w zakresie, w jakim dokonano tą regulacją naruszenia zasady ochrony praw nabytych, zaufania obywatela do państwa prawa i stanowionego przez niego prawa, niedziałania prawa wstecz, powodującego

${ }^{63}$ Por. Prezydent podpisał ustawę dezubekizacyjna, https://www.mswia.gov.pl/pl/aktualnosci/15575,Prezydent-podpisal-ustawe-dezubekizacyjna.html (dostęp: 30 VIII 2018); M. Kruk, IPN sprawdzi każdego emerytowanego mundurowego, http://gospodarka.dziennik. $\mathrm{pl} /$ emerytury-i-ofe/artykuly/545383,ipn-emerytury-mundurowi-dezubekizacja.html (dostęp: 30 VIII 2018); Sejm odrzucit wniosek o informacje ws. społecznych skutków ustawy dezubekizacyjnej, http://www.gazetaprawna.pl/artykuly/1163660,sejm-odrzucil-wnioseko-informacje-ws-spolecznych-skutkow-ustawy-dezubekizacyjnej.html (dostęp: 30 VIII 2018); Niekonstytucyjna dezubekizacja. "Decyzje śmierci”, https://wiadomo.co/niekonstytucyjna-dezubekizacja-decyzje-smierci/ (dostęp: 30 VIII 2018).

${ }^{64}$ Por. Osiem tysięcy osób chce "ułaskawienia” od ustawy dezubekizacyjnej, https://wiadomosci.onet.pl/tylko-w-onecie/osiem-tysiecy-osob-chce-ulaskawienia-od-ustawy-dezubekizacyjnej-resort-blaszczaka-ma/4j277y6 (dostęp: 30 VIII 2018).

${ }^{65}$ Komunikat ws. odwołań od decyzji Dyrektora ZER MSWiA, http://bip.warszawa.so.gov. pl/artykuly/292/xiii-wydzial-ubezpieczen-spolecznych (dostęp: 30 VIII 2018).

${ }^{66}$ Por. Trybunat Konstytucyjny przyblokuje sprawy bytych funkcjonariuszy PRL, http:// serwisy.gazetaprawna.pl/emerytury-i-renty/artykuly/1103666,trybunal-konstytucyjny-obnizenie-emerytur-bylym-funkcjonariuszom-prl.html (dostęp: 30 VIII 2018); pytanie prawne zostało zarejestrowane w Trybunale Konstytucyjnym pod sygn. P 4/18. 
nierówne traktowanie części funkcjonariuszy w porównaniu z tymi, którzy rozpoczęli służbę po raz pierwszy po dniu 11 września 1989 r., skutkujące ich dyskryminacją" oraz „z uwagi na sposób i tryb uchwalenia zaskarżonych przepisów oraz wątpliwości, czy spełnione zostały merytoryczne przesłanki do ich uchwalenia" ${ }^{\prime \prime 7}$.

\section{Podsumowanie}

Temat przysługujących policjantom świadczeń emerytalnych jest bardzo interesujący ze względu na różnorodność tych świadczeń w ramach jednej formacji. Ustawa o zaopatrzeniu emerytalnym funkcjonariuszy służb mundurowych przewiduje różne możliwości nabycia świadczeń emerytalnych oraz podnoszenia ich wysokości. Powyższe często powoduje problemy interpretacyjne przepisów prawnych wobec wielu odesłań do różnych jednostek redakcyjnych wskazanej ustawy. Co do zasady należy jednak wskazać, że świadczenia emerytalne przysługujące funkcjonariuszom służb mundurowych, w tym policjantom, są diametralnie różne od tych, które otrzymują pracownicy cywilni z Funduszu Ubezpieczeń Społecznych. Głównymi elementami różniącymi emeryturę policyjną od cywilnej są warunki, których spełnienie upoważnia do nabycia praw emerytalnych, możliwość podnoszenia wysokości świadczenia oraz wypłacanie świadczenia z budżetu państwa. Powyższe uprzywilejowania powodują, że emerytura policyjna jest korzystniejsza od cywilnej.

Preferencje emerytalne przysługujące funkcjonariuszom mundurowym były traktowane głównie jako podziękowanie za trud służby. Jak już wcześniej wspomniano, m.in. w orzeczeniach sądów administracyjnych czy TK wskazuje się, że pewne uprzywilejowanie służb mundurowych jest społecznie uzasadnione i dopuszczalne ze względu na charakter wykonywanych czynności służbowych. Również z tego powodu służby mundurowe objęte są odrębnym stosunkiem zatrudnienia, który nie mieści się w prawie pracy, tylko w sferze prawa publicznego.

Przyznane pierwotną ustawą z dnia 18 lutego 1994 r. o zaopatrzeniu emerytalnym funkcjonariuszy Policji, Agencji Bezpieczeństwa

${ }^{67}$ Emerytury i renty bylych funkcjonariuszy pełniacych stużbę na rzecz totalitarnego państwa, http://trybunal.gov.pl/s/p-418/(dostęp: 30 VIII 2018). 
Wewnętrznego, Agencji Wywiadu, Służby Kontrwywiadu Wojskowego, Służby Wywiadu Wojskowego, Centralnego Biura Antykorupcyjnego, Straży Granicznej, Straży Marszałkowskiej, Służby Ochrony Państwa, Państwowej Straży Pożarnej, Służby Celno-Skarbowej i Służby Więziennej oraz ich rodzin ${ }^{68}$ uprawnienia emerytalne stopniowo zostawały ograniczane, aż do chwili obecnej, kiedy wprowadzono zasadę, że emeryturę otrzyma funkcjonariusz po odbyciu 25 lat służby i osiągnięciu 55 lat życia. Powyższe w uzasadnieniu projektu zmieniającego ustawę o zaopatrzeniu emerytalnym funkcjonariuszy służb mundurowych zostało wytłumaczone tym, że służby mundurowe mają "uprzywilejowany system emerytalny, co w obecnych realiach społeczno-ekonomicznych nie znajduje ani akceptacji społecznej, ani uzasadnienia z powodu kosztowności i nieefektywności", zmiana niezbędna jest ze względu na "sprawiedliwość społeczną" oraz brak "poparcia społecznego [...] dla dalszego utrzymywania dotychczasowych przywilejów dla służb mundurowych". Wskazane tłumaczenie potrzeby wprowadzenia zmian w systemie emerytalnym służb mundurowych powoduje, że wymienione wcześniej elementy odróżniające służbę od pracy ulegają pewnemu zatraceniu, a pełnienie służby nawet $\mathrm{z}$ narażeniem życia nie jest już tak jak kiedyś wynagradzane. Powyższe zmiany powodują również, że zawód policjanta nie cieszy się takim zainteresowaniem jak wcześniej, co przekłada się na liczbę wolnych stanowisk oraz samych osób służących w formacji. Kolejnym czynnikiem powodującym negatywne nastroje wśród funkcjonariuszy mundurowych jest ingerowanie ustawodawcy w tzw. prawa nabyte związane z wprowadzeniem zmian w ustawie o zaopatrzeniu funkcjonariuszy służb mundurowych ustawą dezubekizacyjna, która miała odebrać przywileje "wrogom narodu”. Wprowadzona reforma objęła wszystkie osoby, które pełniły służbę w szeroko pojętej służbie bezpieczeństwa, bez względu na ich wcześniejszą weryfikację (funkcjonariusze, którzy pełnili służbę na rzecz państwa totalitarnego po zmianach ustrojowych w Polsce przechodzili weryfikację, która umożliwiała im dalsze pełnienie służby w nowo powstałych strukturach) ${ }^{69}$ i dalszą służbę w wolnej Polsce. Zmiana dotycząca tej reformy spotkała

${ }^{68}$ Dz.U. Nr 53, poz. 214.

${ }^{69}$ Uchwała nr 69 Rady Ministrów z dnia 21 V 1990 r. w sprawie trybu i warunków przyjmowania byłych funkcjonariuszy Służby Bezpieczeństwa do służby w Urzędzie Ochrony Państwa i w innych jednostkach organizacyjnych podległych Ministrowi Spraw Wewnętrznych oraz zatrudniania ich w Ministerstwie Spraw Wewnętrznych (M.P. Nr 20, poz. 159). 
się z negatywną oceną związków zawodowych formacji mundurowych ${ }^{70}$ oraz Sądu Najwyższego ${ }^{71}$ już na etapie procesu legislacyjnego.

Wydaje się, że obecnie niezbędne byłoby wprowadzenie kilku zmian dotyczących świadczeń emerytalnych funkcjonariuszy Policji. Po pierwsze, ze względu na charakter pełnienia służby, stawiane wymagania przed funkcjonariuszami oraz odrębność służby od prawa pracy zasadne jest utrzymanie odmiennego systemu zaopatrzeniowego, a dodatkowo rozważenie przywrócenia pełnych przywilejów emerytalnych. Taki zabieg legislacyjny spowoduje, że zawód policjanta znowu zacznie być bardziej atrakcyjny dla kandydatów oraz podniesie morale służących już policjantów. Zasadne byłoby również utrzymywanie jednolitych uprawnień emerytalnych wśród wszystkich funkcjonariuszy, bez dzielenia ich na grupy według daty wstąpienia do formacji. Wpłynie to na uproszczenie regulacji prawnych oraz wyrówna uprawnienia wszystkich policjantów.

\section{POLICE PENSION - ONE BENEFIT WITH MANY ELEMENTS DETERMINING ITS SHAPE}

\section{S u m mary}

The article discusses the pension of police officers upon their retirement and is an analysis of the rules related to the granting police pensions and the determinants conditioning their amount and form.

Police officers, as well as other representatives of uniformed services, are covered by the pension system which differs significantly from the general pension system provided by the Social Insurance Fund. This difference results mainly from the nature of the police officers' work and the duties imposed on them. The differences are manifested by the rights granted to officers, which include, among other things, the possibility of a faster retirement benefit in comparison with other workers.

The current legal provisions regulating the matter of granting and shaping benefits of police officers' pensions have been reviewed several times. As a result, retired officers have been now covered by a police pension in three options. These options differ in terms of the length of service for which a policeman in question is entitled to a pension and the manner in which the pension can be increased. Classification into any of the possible pension variants depends on the date of commencement of service in the uniformed formation. In addition, regulations were

${ }^{70}$ Opinia Forum Związków Zawodowych, http://orka.sejm.gov.pl/Druki8ka.nsf/0/ 246880079E16A43BC1258090004A9632/\%24File/1061-003.pdf (dostęp: 30 VIII 2018).

${ }^{71}$ Uwagi Sądu Najwyższego, http://orka.sejm.gov.pl/Druki8ka.nsf/0/47A50D2CC87C2BD3C1258089004AF9B5/\%24File/1061-001.pdf (dostęp: 30 VIII 2018). 
also introduced involving the possibility of reducing the size of pension in the case of officers employed at the time when Poland was a totalitarian state. The variety of benefits granted within a single formation and the complexities associated with the regulation of police pensions cause many problems arising from their interpretation and the determination of pension benefits for present and former officers.

Keywords: Police - uniformed services - police pension - retirement provision officers 